ISSN 2054-0930 (Print), ISSN 2054-0949 (Online)

\title{
THE PROCUREMENT THRESHOLD IN THE PROCUREMENT ACT OF GHANA, ACT 663 (2003) AS AMENDED: ANY IMPACT ON INVENTORY MANAGEMENT OF TERTIARY INSTITUTIONS IN GHANA?
}

\author{
Emmanuel Mensah \\ Procurement Unit, Cape Coast Technical University, Cape Coast, GHANA
}

\begin{abstract}
The Ministry of Education is one of the ministries in Ghana that spend a chunk of their budgetary allocation on procurement of commodities other than personal emolument. In the Ghanaian public sector, the acquisition of materials for operations is through the application of Ghana's Public Procurement Act, Act 663 (2003) as amended in Act 914 (2016). This study focuses on the effects of procurement threshold in Ghana's Procurement law on inventory management of tertiary institutions in Ghana. Specifically, the study focuses on establishing how procurement thresholds enshrined in the Public Procurement Act of Ghana affects quantities of items purchased for inventory. The study chooses the Cape Coast Technical University as its case study. In a descriptive study, forty (40) respondents were sampled and questionnaires were administered to them. Preliminary analysis were made in a tabular form and presented on a bar chart on the basis of the study objectives. After interpreting the data, the results of the study revealed that procurements thresholds instituted in the Public Procurement Act which are used to determine the procurements methods and approval authorities based on the contract value have some impact on inventory management. Among others, the study suggests that these thresholds must be reviewed at least every four (4) years to reflect current economic trends and situation of the country and again, frequent monitoring and evaluation of procurement entities by the Public Procurement Authority (PPA) must be strengthened to ensure compliance of the Procurement law in Ghana.
\end{abstract}

KEY WORDS: inventory, management, stock, threshold, Procurement Act of Ghana,

\section{INTRODUCTION}

Inventory control has long been viewed as a function of the organization that ensures that there is adequate supply of materials to keep the organization running. Inventory management, therefore, is thought to be primarily about specifying the size and placement of the various items in stocked goods. It is, therefore, required at different locations within a facility of multiple locations of supply network to protect requisition and planned course of production or operation of an organization against the random disturbances of running out of stock. The Public Procurement Act of Ghana, Act 663 (2003) as amended in Act 914 (2016) on its inception has impacted greatly on the inventory management of public institutions. Public institutions, therefore, are expected to develop inventory management systems that will aid the application of the Public Procurement Act to ensure inventory availability for operation at all times without overstocking. Achieving a perfect balance between the application of procurement threshold and inventory management processes in a public institution and still adhering to the Procurement Law of Ghana require time and a great deal of experience and human effort. 
Public institutions were the major target of the Government of Ghana's procurement reform programme. The framers of the Procurement Act detailed organizations that the Procurement Act of Ghana applies to. They include all public institutions that take any funding from the government. These included but was not limited to Central Management Agencies, Ministries, Departments, and Agencies (MDAs), State-Owned Organizations (Agencies), State-Owned Enterprises (when using public funds), Government institutions, Public Universities, Colleges, Hospitals, Banks and Financial institutions owned by Government and institutions established by government for the general welfare of the public.

The law was principally made for these institutions because, according to the Government of Ghana's Financial Reform Programme which started in 1992, over seventy percent 70\% of government revenue was used for procurement apart from the percentage spent on personal emoluments. Dwelling on the above statement, it is clear that the procurement reform was necessary to achieve financial stabilization of the country's economy. When the procurement law got promulgated, however, it did not prescribe an inventory management policy which will work in close synchronism with the Procurement Act for the smooth operation of the business of acquiring inventory and maintaining constant availability of stock within a reasonable time for the operation of the organization. Inventory investment for tertiary public institution takes up a substantial amount of their total budget next to personnel emolument; yet, inventory control is one of the most neglected areas in most public institutions. Many public institutions have excessive amount of cash tied up due to accumulation of inventory sitting at their stores. With this as a major problem identified, the objective of the study is to ascertain how the procurement thresholds in the Public Procurement Act of Ghana affects quantities of items purchased for inventory and to propose recommendations that could be introduced to mitigate or compliment the effect of procurement threshold of the Procurement law of Ghana, Act 663 (2003) as amended on inventory management in Ghanaian public tertiary institutions.

The main research question that this paper seeks to answer is "what is the effect of procurement threshold of the Procurement Act of Ghana with respect to quantities of inventory purchased?" The study hopes that any information derived from the findings could be used to improve the procurement process in public organizations and assist them to identify a system of procurement processes and procedures that should be put in place to achieve a balance between not locking up funds that could be used for other administrative functions and having materials ready for operations while observing fully the procurement threshold policy in the Public Procurement Act of Ghana.

\section{Defining Inventory Management}

Bowersox et al. (2012) define inventory management by quoting APICS which defines inventory as those stock or items used to support production and operations of an organization (raw materials, spare parts, consumables and work in progress). Indeed, according to Bowersox et al. (2012), inventory control is concerned with the acquisition, storage, handling and the use of inventories so as to ensure the availability of inventory whenever needed, providing adequate cushioning for contingencies, deriving maximum economy and minimizing wastage and loss. Inventory management, therefore, deals with decisions regarding the amount of materials that is available within the supply system of 
organization (supply levels). Thus, it is worth noting that inventory management encompass the management of materials in right quantities such that there are materials available at all times taking into consideration the acquisition cost, the holding cost of the materials and the lead time for acquiring the materials. Effective inventory management, therefore, is essential for the operation of every organization (Greasly, 2013)).

Many reasons have being advanced for why organizations hold excess inventory. Among these reasons are variation in demand and production, poor quality items supplied particularly during emergencies, unreliable suppliers and poor transportation system (Francis et al., 2014). Equally, Choi (2016) and Chopra and Meindl (2015) also add that there have also been reasons justifying why the amount of inventory kept for operation should be kept at a very minimum level, among which are the carrying cost, storage space, materials handling and issues of expiration \& obsolete materials and holding cost of inventory.

In today's business world, organizations are moving towards keeping small inventory, practising lean manufacturing and ensuring that Total Quality Management (TQM) is incorporated in the organization's supply chain system so as to optimize inventory usage and also ensure judicious and profitable use of funds. Das (2016) posits that keeping of large inventory is, therefore, not to be encouraged and so, most organizations should not worry about availability of stock or holding excess of it. As such, it is just in the area of time inventory control where the keeping of inventory is almost non-existent that most companies are now looking at and is being practiced by many multinational firms. In his estimation, Das (2016) explains that this helps to reduce and almost eliminate the cost of holding inventory. However, there is always the factor of unforeseen contingencies in business operations and inventory management. Determining the exact amount of materials needed to cover these unforeseen contingencies is very important to every organization just as the rapidity or the speed that organization can move to acquire materials to cover the shortages is also very essential.

In Ghana, the Procurement Act 663 (2003) as amended in the Act 914 (2016) prescribes the processes and steps that public institutions must follow to acquire goods, works and services for their operations. The law must be strictly adhered to as it prescribes punishment for doing contrary activities to what is prescribed. As such, the mechanism that initiates inventory replenishment must be such that, the duration needed for the replenishment must synchronize perfectly with the time that is needed to complete government procurement processes to place orders so that the suppliers supply the items without encountering shortages. This has often been difficult.

\section{Reasons for Keeping Inventory}

To avoid shortages of materials for operations and also have best value for money spent on materials, there are some frequently advanced reasons for keeping stock. According to Cachon and Terwiesch (2017), time is one such reason. He explains that time helps to bridge the time lags in the procurement and supply of items in the supply chain to the user. Certain amount of inventory is maintained to be used in the period of the lead time. However, inventory is to be maintained for consumption during variation in lead time. To address problems of lead time, items can be ordered many days in advance. It must be 
noted that this could also result in increase in inventory when the new items arrive before items in the stores reach their minimum level. Ordering materials earlier will also mean that buffer stock may not be necessary as items will always be available before shortages occur.

Dawe-Lu (2011) also adds that inventory is also kept as a result of uncertainly in the demand of the items. Thus, excess inventory is maintained as buffer to meet uncertainties in the supply of good to meet the customers demand. This reason cited by Dawe-Lu (2011) is complemented by Ivanov (2018) who adds another very important reason that it is kept to enjoy economies of scale on cost that is incurred on the ordering and logistics involved in the movement of the items such as the warehousing, handling and transport charges. Finally, Foster et al. (2016) add that inventory is kept to take advantage of better prices for large quantities of goods. When an organization notices better prices for a material they use, there is always the desire to take advantage of such better prices that have been given by the suppliers.

\section{Problems Associated with Holding Stock}

Various reasons have been advanced as reasons for holding stock. Zipkin (2000) noted the following as among the problems associated with holding inventory. These, he noted, include among others, potential for damage or obsolescence, expiration and evaporation of liquids due to long shelf life of the material kept in stock; loss of value of items because when new types and models with higher specification are introduced, the old ones tend to lose their value with time; and theft. It is noteworthy that the longer the time of storage, the higher the probability of theft occurring at the Stores unit. Fraud has also being cited as a cause of the problems associated with holding stock. According to Stadtler et al. (2015), keeping goods for a very long time means the organization will potentially begin facing substantial risk in having fraud since stock can be transformed into cash easily.

\section{Figure 1: Average Annual Fixed Order Cost K/Q and the Annual Holding Cost KQ/2 as a Function of $\mathbf{Q}$}

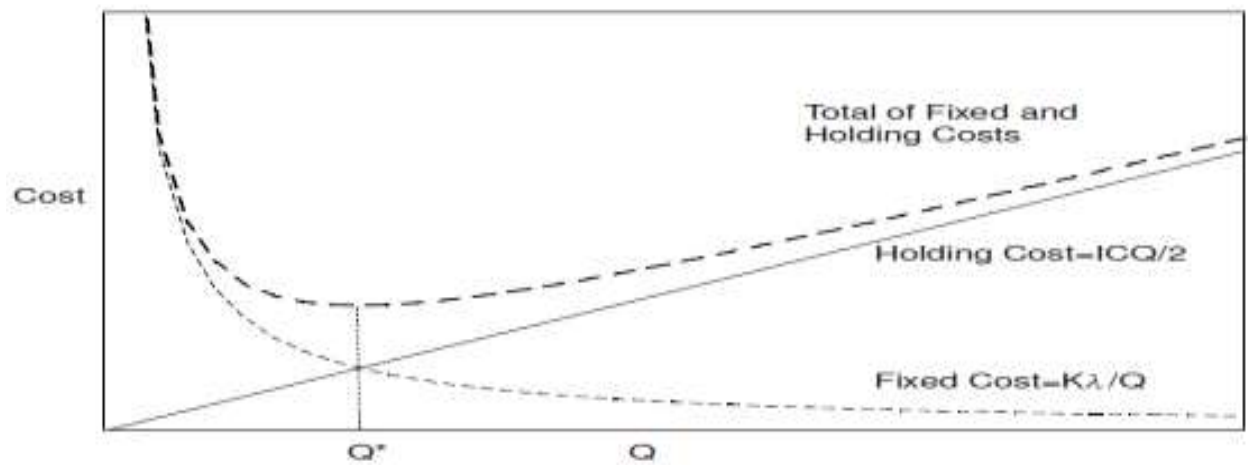

Figure 1 shows the plot of the average annual fixed order cost K/Q and the annual holding cost $\mathrm{KQ} / 2$ as a function of $\mathrm{Q}$. The average annual fixed order cost decreases as quantity increases because fewer orders are placed.

\section{The Effectiveness of the EOQ Model as a Means of Deciding Replenishment}

In the real world, it is often difficult to estimate the model's parameters accurately. The cost and demand parameters values used in the model are best approximations to their actual 
values used in the model. The policy of computing the EOQ using the approximated parameters cannot be optimally stated (Sharma, 2006). The optimal policy cannot be computed without knowing the true value of the model's parameters. Clearly, if another policy is used, the realized cost will be greater than the cost of the true optimal policy, according to Thai (2009).

\section{The Implementation of the Procurement Threshold in Ghana}

Before the promulgation of the Public Procurement Act 663 (2003) as amended in the Act 914 (2016), the government of Ghana had no specific laws in its statute books governing the procurement activities in which public funds are used. Public organization using funds from the government, therefore, had to develop their own policies and guidelines as well as manuals for the acquisition of their materials for operation. Indeed, the government had no comprehensive procurement law in place for public buying. Hitherto, policies and guidelines were developed by public organizations to help them in their procurement activities which lacked legal backing. Also, there was no central body with the expertise to oversee or regulate sound procurement practices. There was absence of clearly defined roles, responsibilities and authority for procurement entities, which resulted in the overlapping of procurement functions between the central government/headquarters of organizations and their regional and district subsidiaries. Whilst the government of Ghana found it difficult to control procurement at the regional and district levels due to lack of clearly defined thresholds for their procurement activities, the district and the regional subsidiary organizations were also grappling with the issue of the central body buying and dumping on them items they do not need immediately because of lack of threshold establishing each other's area of jurisdiction in terms of procurement activities.

Added to the above is the important factor of the State not having any comprehensive legal regime to safeguard public procurement as public funds are committed to contract. Mention can also be made of the unavailability of rules and regulations to guide, direct, train, and monitor public procurement. Lack of thresholds in procurement policy also meant that wrong procurement methods are applied for the procuring government contract; hence exposing government to getting poor value on money spent (Christopher, 2011). An example is the use of single sourcing applied to purchased items that are easy to obtain on the market with competitive prices and price quotation being used to select contractors for government's multibillion dollar projects. Also, lack of threshold means the blurring of responsibility of approving government procurement. This gave rise to the situation where district or regional agencies of the government awarded contracts for which they had no expertise for awarding and managing. There are also situations where the central government/headquarters moves to the district and the regional offices and subsidiaries to award contracts without taking into consideration the local content factor of the contract. It is clear that when those organizations using public funds develop their own policies and guidelines on how procurement will have to be done in the organizations, it will result in fair competition.

\section{Benefits of Implementing Procurement Threshold}

Procurement threshold helps the procuring entity to properly define the roles, responsibilities and the authority for approvals between the government, its various procurement entities and the procurement structures set out by the government to oversee 
public procurement. In Clegg, MacBryde and Dey (2013), focus is put on the need for setting threshold limits for approval by different levels of authority within an establishment; however, they did not highlight it from the point of view of the public sector. They believe that using procurement threshold serves as guidelines to dictate and enforce the procurement method which will have to be used on any contract. From their point of view, it means procurement threshold helps in the determination of award of procurement contract. In addition, the use of procurement threshold, as it is in Ghana's Procurement law, establishes the procurement method for any specific contract. This will be based on the value of the contract and also the various approving authorities. More, it gives room for the contract value to be established and also allows the contract to be studied and reviewed by higher and more knowledgeable personnel in the procurement structure once the contract value goes beyond a specific value. This position is supported by Dolgui and Proth (2016) in their book Supply Chain Engineering: Useful Methods and Techniques. It is also worthy of note that procurement thresholds are also sometimes used to increase or decrease the amount of money spent by a procurement entity on the quantity of a material that a procurement entity can purchase (Christopher, 2011; Ivanov and Sokolov, 2010; and Ivanov, 2018).

Establishing procurement thresholds have really helped governments, and Ghana is no exception, to deal with contracts (goods, works and services) that are only available from a particular contractor or if the particular contractor has an exclusive right in respect of the said contract and no reasonable alternative or substitute exists (as in the single sourcing clause in the Public Procurement Act of Ghana, 663 (2003), Sections 40 and 41 and its subsequent amendment. In fact, it serves as means of appropriately passing over procurement contracts to well knowledgeable persons in terms of the procurement method and approval.

\section{Challenges Facing the Application of the Procurement Threshold}

According to Christopher (2011) and Ivanov and Sokolov (2010), the benefits of procurement threshold are widely acknowledged, but down sides should not be underestimated. Because of this, Dolgui and Proth (2016) advise that implementing procurement threshold implies facing several challenges. Reading through the Public Procurement Act 663 (2006) as amended, there are some challenges that come forth as a result of the implementation of the procurement threshold as part of contract awarding procedure. It has been established by most authors on inventory control management as well as Supply Chain Management and many other eminent writers on the subject like Ivanov (2018) and Dolgui and Proth (2016) that inventory control is linked heavily with the operations and the sustenance of the organization. They also established that, holding inventory for operation has a cost and that the higher the value of inventory in stock, the more expensive the organization's inventory holding cost. In the same vein, these same studies and theories propounded by these writers and others also did not hold back to point out that holding little inventory also comes with a cost. That is, the cost of spending very little of your capital on inventory is good because funds will be available for other operations in the organization. 


\section{METHODOLOGY}

The study is a descriptive survey that sought to explain the effect of procurement threshold of the Procurement Act of Ghana, Act 663 (2003) on inventory management of tertiary institutions in Ghana in terms of acquisition and holding cost, lead time and the quantity of the items purchased. The study is descriptive because the researcher describes the situation as it was being presented. Two types of data, primary and secondary were used for this research work to provide the necessary input for analysis and arrive at an outcome for the research. The primary data was collected specifically from respondents on the topic under consideration from the Cape Coast Technical University adopted for the research. Aside the secondary data sourced from published materials, the primary data collected for the study were collected through questionnaires distributed to employees of Cape Coast Technical University selected for the study.

The Cape Coast Technical University has a work force of three Hundred and Fifty Seven (357). Cape Coast Technical University was selected because it is a state-owned organization that uses public funds to undertake their procurement. Thus Cape Coast Technical University applies the procurement threshold of the Procurement Act of Ghana, Act 663 (2003) as amended when undertaking purchases. The researcher only concentrated on the members of staff of the institution who are directly involved in procurement and inventory control management activities for the institution. Their knowledge and experience was much needed in answering the questions involved in solving the research questions. They were made up of staff of the Procurement Unit, Stores Unit, Finance Section, Internal Audit, staff of the office of the Head of the Institution, as well as various user-departments where requests to purchase and requisition for materials are generated.

In order to focus effectively on and fulfil the purpose of better understanding the outcome of the topic under study, the non-probability sampling was used for the study. The sampling method chosen for this study was convenience sampling. This means that the researcher had to find respondents who are willing to participate in the study and also knowledgeable on the procurement laws of Ghana as well as inventory management before they were allowed to answer the questionnaire. The sample size was carefully chosen to reflect the purpose and objective of the study. Forty (40) respondents consisting of Procurement Office staff, some staff of the various user-departments of the institution, the Finance Directorate, Internal Audit Directorate, Head of Entity (Head of Institution)'s Office and Stores and Supply Section were sampled for the purposes of this research work. The researcher believed the respondents sampled had in-depth knowledge on Ghana's procurement laws, as well as inventory control management of the Technical University. Questionnaire was developed from the research objectives. The questions were constructed in a closed ended form to make them easier to answer. They were aimed at obtaining a demographic data, perception and challenges of the policy of procurement threshold of the Procurement law of Ghana, Act 663 (2003) as amended on inventory management. On the average, it took about forty minutes to provide answers to all the questions on the questionnaire. Statistical frequency distribution tables and charts were used to present the findings for easy interpretation and easy identification of the flow of patterns and relationship between the variables. 
ISSN 2054-0930 (Print), ISSN 2054-0949 (Online)

\section{Analysis of Data}

\section{Educational Background and Work Experience of Respondents}

Due to the specialized nature of the study, respondent needed for the study were to have a considerable knowledge on the subject under study. It was noticed that this could be obtained through having academic qualification or experience on the job. A combination of academic knowledge and experience through practice provides the best means of being knowledgeable on the subject. A distribution of the respondents' academic or educational qualification was, therefore, essential for this research. As noted earlier, the questionnaires were distributed to departments, sections, offices and units connected with the procurements process and inventory of the Technical University.

Table 1: Educational Level of Respondents

\begin{tabular}{|c|c|c|}
\hline Response & Frequency & Percentages (\%) \\
\hline SSSCE & 2 & 5 \\
HND & 4 & 10 \\
Degree & 8 & 20 \\
Master's Degree & 18 & 45 \\
PhD & 2 & 5 \\
Professional Qualification & 6 & 15 \\
\hline Total & $\mathbf{4 0}$ & $\mathbf{1 0 0}$ \\
\hline
\end{tabular}

Source: Field Work, Nov. 2019

From the results of the data presented above in table 1, it could be seen that 18 out of the 40 respondent had Master's Degree making 45\% of the responses received.. Eight (8) respondents had First Degree providing $20 \%$ of the data generated. 6 respondents had professional qualification making up $15 \%$ of the responses collected from responses. Four (4) respondents had HND making $10 \%$ and two (2) people had a $\mathrm{PhD}$ degree which is $5 \%$ of the responses gathered. The last two people also had SSCE certificate.

The distribution above shows the entire respondents selected had the minimum academic knowledge needed to understand the concepts in procurement threshold and inventory management.

\section{Figure 2: Educational Level of Respondents}

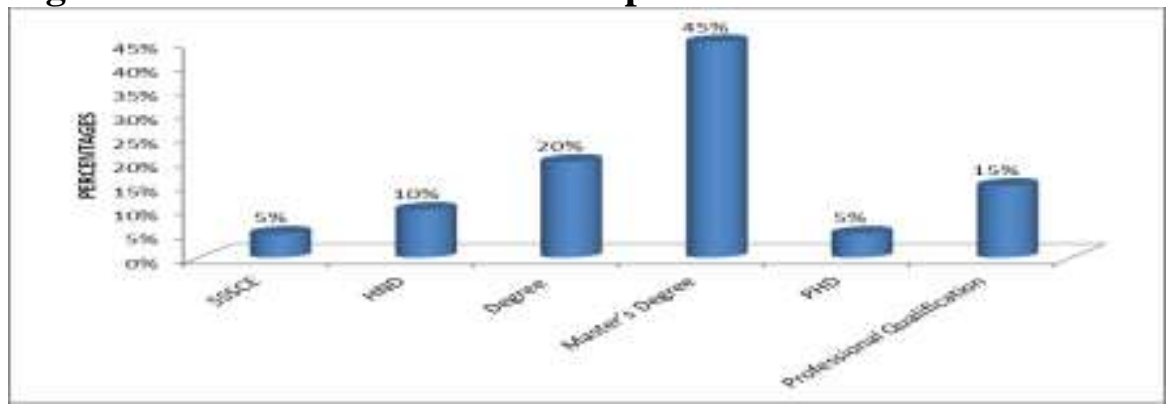

Source: Field work, Nov. 2019 
Table 2: Working Experience of Respondents

\begin{tabular}{|c|c|c|}
\hline Response & Frequency & Percentages (\%) \\
\hline Below 5yrs & 6 & 15 \\
$6-10$ yrs & 16 & 40 \\
$11-15$ yrs & 10 & 25 \\
$16-20 y r s$ & 6 & 15 \\
Above 20yrs & 2 & 5 \\
\hline Total & $\mathbf{4 0}$ & $\mathbf{1 0 0}$ \\
\hline
\end{tabular}

Source: Field work, Nov. 2019

From the results of the data presented above in table 2, ten (10) of the 40 respondents had worked between 11 and 15 years which means that $25 \%$ of the responses for this study came from staff with work experience of between 11 years and 15 years. As many as 16 respondents making up 40\% of responses were from staff with between 6 years and 10 years' experience. There were 6 respondents who had between 16 and 20 years and another batch of 6 respondents who had below 5 years of experience. They all provided $15 \%$ of the data received. Only 2 respondents had more than 20 years' experience providing $5 \%$ of the data. This means that all the respondents had also gathered considerable knowledge from work experience to provide the needed responses for analysis of the study. Below is the bar chart showing the distribution of work experience of respondents as represented in figure 3 .

\section{Figure 3: Respondents Distribution of Work Experience}

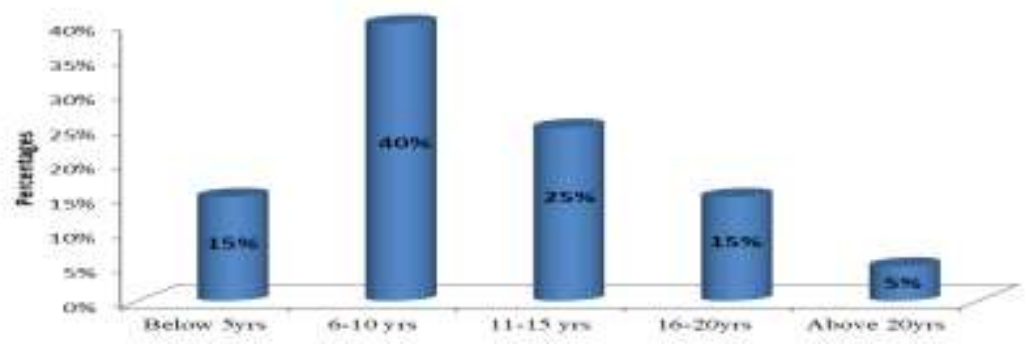

Source: Field work, Nov. 2019

\section{Effects of Procurement Threshold on Lead Time of Inventory Acquisition}

The main objective is to ascertain whether procurement threshold has effect on lead time on inventory acquisition. The researcher wanted to know the procurement method frequently used by the Cape Coast Technical University, why it is the preferred procurement method and its effect on procurement. Table 3 below shows the data analysis of the institution's distribution of the procurement method frequently used for acquisition of materials. 
Table 3: Procurement Method Used by the Institution

\begin{tabular}{|c|c|c|}
\hline Response & Frequency & Percentages (\%) \\
\hline Price quotation & 35 & 88 \\
National competitive & 5 & 12 \\
Restricted tendering & 0 & 0 \\
Single sourcing & 0 & 0 \\
\hline Total & $\mathbf{4 0}$ & $\mathbf{1 0 0}$ \\
\hline
\end{tabular}

Source: Field work, Nov. 2019

From table 3 above, it was observed that 35 out of the 40 questionnaire received translating into $88 \%$ of the answers indicated that price quotation is the predominantly used procurement method. Only five (5) people indicated national competitive tendering. There were no responses on Restricted Tendering and Single Sourcing procurement indicating that these methods are rarely used. The use of price quotation as a procurement method for the acquisition of material means that the Technical University's purchases do not amount to a hundred thousand Ghana Cedi ( $\mathrm{GH} \not 100,000.00)$. This also means that limited quantities are purchased and re-ordering is frequent.

This was confirmed in interviews conducted to obtain further information on this assumption. During the interviews it was revealed that most of the price quotation purchases do not actually exceed thirty thousand Ghana cedis $(\mathrm{GH} \notin 30,000.00)$ and they were usually approved by the entity head. Probing further to find the reason for buying in bits and pieces contrary to section 21 (5) of the Public Procurement Act of Ghana, Act 663 (2003) as amended, which stipulates that a buyer shall not divide a procurement order into parts or lower the value of procurement order to avoid the application of the procedures for Public Procurement in the Act., it became clear that price quotation is used to procure contracts in order to avoid lengthy procurement procedures due to the application of thresholds and also to reduce lead time as the Technical University keeps very little stock as a policy to avoid over-stocking to lock funds meant for other important school work. Below in figure 4 is a bar graph of the information in table 3.

\section{Figure 4: Procurement Method Used by the Institution}

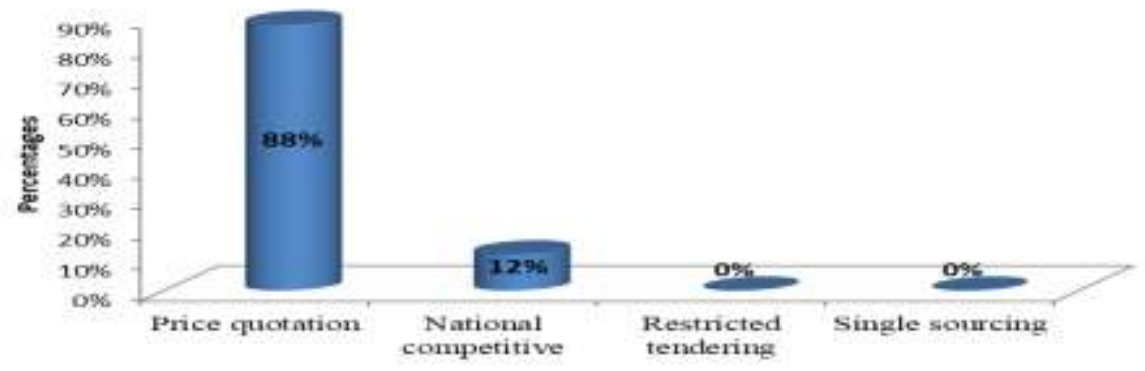

Source: Fieldwork, Nov. 2019 
ISSN 2054-0930 (Print), ISSN 2054-0949 (Online)

Again, in order to further test the institution's justification of avoiding lengthy procurement procedures, the respondents were asked to state the number of days it usually takes to obtain concurrent approval whenever the institution had to apply for concurrent approval for a contract beyond the threshold of Entity Tender Committee and the table 4 below shows the responses.

Table 4: Duration Taken to Obtain Concurrent Approval by the Institution from Higher Approval Authority

\begin{tabular}{|c|c|c|}
\hline Response & Frequency & Percentages (\%) \\
\hline Between 1-10 days & 4 & 10 \\
Between 11-20 days & 4 & 10 \\
Between 21-30 days & 2 & 5 \\
After 30 days & 30 & 75 \\
\hline Total & $\mathbf{4 0}$ & $\mathbf{1 0 0}$ \\
\hline
\end{tabular}

Source: Fieldwork, Nov. 2019

From the above, it is noticeable that 30 respondents making $75 \%$ of the answers obtained said that approval is obtained after 30 days and 4 respondents believe it is between 1 and 10 days, making $10 \%$ of the responses. Another 4 believe it is between 1 and 10 days making another $10 \%$. Only two respondents making $5 \%$ of the answers received said it is between 21 and 30 days. An inspection of documents at the Procurement Directorate of the institution confirms what most respondents were saying, which is after 30 days. This reenforces the respondents' belief that procurement threshold has an effect on lead time of contract administration of the Technical University.

Table 5: Does Procurements Threshold Affect the Overall Inventory Management Function?

\begin{tabular}{|c|c|c|}
\hline Response & Frequency & Percentages (\%) \\
\hline Agree & 30 & 75 \\
Neutral & 2 & 5 \\
Disagree & 8 & 20 \\
\hline Total & $\mathbf{4 0}$ & $\mathbf{1 0 0}$ \\
\hline
\end{tabular}

Source: Field work, Nov. 2019

From the table 5 above, thirty (30) respondents representing $75 \%$ of the population agree that procurements threshold affects the overall inventory management function of the Technical University; eight (8) respondents representing $20 \%$ of the population disagree that procurement threshold affects the overall inventory management function of the Technical University and two (2) respondents representing 5\% of the population were neutral as to whether procurement threshold affects the overall inventory management function of the Technical University. 
Figure 5: Respondents' Views on the Effect of Procurement Threshold on the Overall Inventory Management of the Technical University.

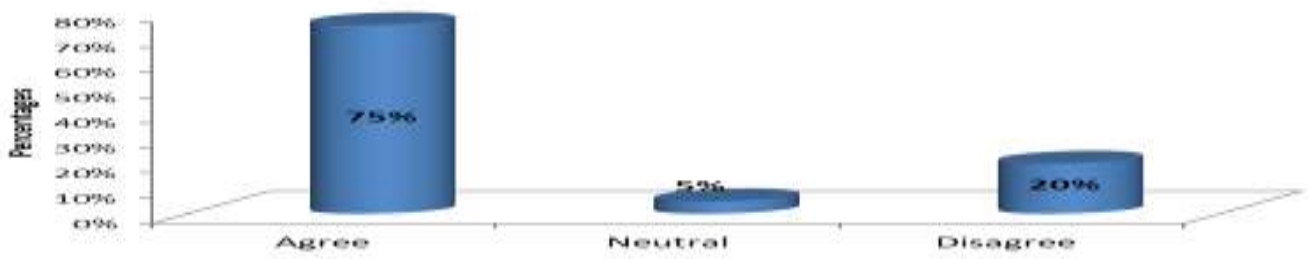

Source: Field work, Nov. 2019

From the analysis above, it could be seen that procurement threshold has an effect on inventory management of universities in Ghana. Using Cape Coast Technical University as a case study, it has become clearer.

\section{CONCLUSIONS AND RECOMMENDATIONS}

The study makes the following conclusion from the analysis made that procurement threshold has an effect on acquisition cost of inventory. In order not to hold excess inventory and incur higher holding cost, the institution selected as a case study prefers holding smaller stock and reordering anytime items in stock reaches the reorder level. The application of procurements threshold to contract means smaller quantities being bought frequently raising the cost of acquisition of inventory. Frequent ordering of materials in smaller quantities to avoid a particular procurement method or approval authority means that the Technical University does not enjoy any economies of scale on some acquisition cost of inventory such as transportation and handling cost or discount on quantity purchased, hence high cost of ordering of inventory.

The study can thus conclude that procurement thresholds in the Public Procurement Acts of Ghana have effects on inventory management of public universities in Ghana, particularly quantities of items purchased judging from the case study area, the Cape Coast Technical University. In view of the foregoing, the following recommendations are being suggested:

- $\quad$ The need for a review of procurement threshold of the procurement laws of Ghana at least every four (4) years to reflect the effect of economic factors such as inflation, exchange rate, taxes and disposable incomes.

- $\quad$ Procurement threshold must be categorized based on the nature and type of organization to reflect on its operational needs and structure.

- $\quad$ The government must come out with a standard inventory managing system for all public institution in the form of legislation to compliment the procurement laws of Ghana.

\section{References}

Bowersox, D. J, Closs, D. J, Copper, M. B. (2012). Supply Chain Logistics Management, $4^{\text {th }}$ edn. Boston: McGrawHill.

Cachon, C. and Terwiesch, C. (2017). Operations Management, 1st edn. Boston: McGraw- 
Hill.

Choi, T. M. (ed). (2016). Service Supply Chain Systems. London: CRC Press.

Chopra, S. \& Meindl, P. (2015). Supply Chain Management: Strategy, Planning and Operation, 6th edn. Pearson, Harlow.

Christopher, M. (2011). Logistics and Supply Chain Management. Creating ValueAdding Networks, 4th edn. FT Press, New Jersey.

Clegg, B., MacBryde, J. and Dey, P. (2013). Trends in Modern Operations Management. International Journal of Operation and Production Management. 33 $(11 / 12)$.

Das, A. (2016). An Introduction to Operations Management. CRC Press, Boca Raton.

Dawe-Lu, D. (2011). Fundamental of Supply Chain Management. Dr. Dawei-Lu and Ventus Publishers, APS.

Dolgui F. L. A. \& Proth, J. M. (2010). Supply Chain Engineering: Useful Methods and Techniques. Springer, Berlin: McGraw-Hill Companies, Inc.

Foster S, T, Sampson, S., Wallin, C. and Webb, S. (2016). Managing Supply Chain and Operations: an Integrative Approach. Pearson

Francis M., Fisher R, Thomas A. and Rowland H. (2014). "The Meaning of 'Value' in Purchasing, Logistics and Operations Management". International. Journal of Production Research. 52(22):6576-6589

Greasly, A. (2013). Operations Management, 3rd edn. New York: Wiley.

Parliament of Ghana: Procurement Act of Ghana (Act 663,2003). (2003). Ghana Publishing Company.

Parliament of Ghana: Amendment $t$ the Procurement Act of Ghana (Act 941,2016). (2016). Ghana Publishing Company.

Sharma, A. K. (2006). Purchasing and Materials Management. New Delhi (India): Anmol Publications PVT. Ltd.

Stadtler, H., Kilger, C. and Meyrs, H. (eds.) (2015). Supply Chain Management and Advanced Planning: Concepts, Models, Software and Case Studies, $5^{\text {th }}$ Ed. Germany: Springer Heidenheim.

Thai, K. V. (2009). International Handbook on Public Administration and Policy in European Union. CRC Press, C. Taylor and Francis group.

World Bank EDSEP/TALIF Loan Agreement. (2004). Ministry of Education/Finance.

Zipkin, P. H. (2000). Foundation of Inventory Management. United States of America.

Ivanov, D. (2010). "A Framework for Aligning (re)planning Decisions on Supply Chains Strategy, Design, Tactics, and Operations". International Journal of Production Research. 48 (13):3999-4017

Ivanov, D. (2018). Structural Dynamics and Resilience in Supply Chain Risk Management. Springer, New York

Ivanov, D. and Sokolov, B. (2010). Adaptive Supply Chain Management. Springer, London. 
European Journal of Logistics, Purchasing and Supply Chain Management

Vol.8 No.2, pp.35-48, May 2020

Published by ECRTD UK

ISSN 2054-0930 (Print), ISSN 2054-0949 (Online)

\section{Appendix}

SECOND SCHEDULE

(Scctions 18, 20, 20A, 20B and 20C)

THRESHOLDS FOR MINISTRIES, OEPARTMENTS AND AGENGIES - APPROVING AUTHORITY

\begin{tabular}{|c|c|c|c|c|c|c|c|c|c|c|c|c|}
\hline \multirow{2}{*}{$\begin{array}{l}\text { Approving } \\
\text { Authorily }\end{array}$} & \multicolumn{3}{|c|}{ Categay A and $B$} & \multicolumn{3}{|c|}{ Castegory C } & \multicolumn{3}{|c|}{ Galegory D' } & \multicolumn{3}{|c|}{ Categry ta } \\
\hline & Coods & Works & Sarvices & Gosds & Wooks & Sencess & Goods & Keaks & Servicen & Gocds & Werks & Sences \\
\hline $\begin{array}{l}\text { Cenlral } \\
\text { Tervider } \\
\text { 2enew } \\
\text { Commitites }\end{array}$ & $\begin{array}{l}\text { Above } \\
1.0000,0000\end{array}$ & $\begin{array}{l}\text { AbONe } \\
15.000,800\end{array}$ & \begin{tabular}{|l} 
Above \\
$1,000.0000$
\end{tabular} & $\begin{array}{l}\text { Abswe } \\
80 Q, 500\end{array}$ & \begin{tabular}{|l|} 
Alowe \\
$1,500,, 000$
\end{tabular} & $\begin{array}{l}\text { Abess } \\
\text { Eco,0:0 }\end{array}$ & $\begin{array}{l}\text { Above } \\
\text { 4ino,000 }\end{array}$ & $\begin{array}{l}\text { Atove } \\
800,000\end{array}$ & $\begin{array}{l}\text { Atove } \\
400,000\end{array}$ & $\begin{array}{l}\text { Atove } \\
200,000\end{array}$ & $\begin{array}{l}\text { Abowe } \\
480,000\end{array}$ & $\begin{array}{l}\text { Abow } \\
200,000\end{array}$ \\
\hline $\begin{array}{l}\text { nility } \\
\text { ender } \\
\text { onmiatee }\end{array}$ & \begin{tabular}{|l|} 
Above \\
100.000 \\
10 \\
$1,000,000$ \\
\end{tabular} & \begin{tabular}{|l}
$\mathrm{Above}$ \\
500,000 \\
10 \\
$15,000,0000$
\end{tabular} & \begin{tabular}{|l} 
Above \\
100,000 \\
10 \\
$1,000,000$ \\
\end{tabular} & $\begin{array}{l}\text { Alove } \\
160,000 \\
10 \\
1000,050 \\
\end{array}$ & \begin{tabular}{|l} 
Abeve \\
150,003 \\
10 \\
$1,500,000$ \\
\end{tabular} & $\begin{array}{l}\text { teoy } \\
160,000 \\
10 \\
800,000\end{array}$ & $\begin{array}{l}\text { A6006 } \\
45,060 \\
10 \\
450,000\end{array}$ & 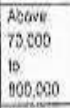 & $\begin{array}{l}\text { AESONe } \\
65,1000 \\
10 \\
440,0000\end{array}$ & 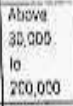 & $\begin{array}{l}\text { Above } \\
45,000 \\
\text { is } \\
400,000\end{array}$ & $\begin{array}{l}A b \% \% \\
30,000 \\
10 \\
200,000\end{array}$ \\
\hline hility & $\begin{array}{l}\text { Up lo } \\
100,000\end{array}$ & $\begin{array}{l}\text { Up } 60 \\
500,000\end{array}$ & $\begin{array}{l}\text { Up lo } \\
100,0 D S\end{array}$ & $\begin{array}{l}0,910 \\
100,000\end{array}$ & $\begin{array}{l}\text { Up lo } \\
150,000\end{array}$ & $\begin{array}{l}\text { Up } 10 \\
160,000\end{array}$ & $\begin{array}{l}\text { Uap } 10 \\
48, \infty C 0\end{array}$ & $\begin{array}{l}\text { Up } 10 \\
76,000\end{array}$ & $\begin{array}{l}\text { U5:16 } \\
45,002\end{array}$ & $\begin{array}{l}50,15 \\
30000\end{array}$ & $\begin{array}{l}\text { Up } 10 \\
45, \infty 00\end{array}$ & $\begin{array}{l}\text { Uplo } \\
30,000\end{array}$ \\
\hline
\end{tabular}

Extract from the Public Procurement Act of Ghana, Act 663 (2003) as amended in Act 914 (2016) indicating the thresholds for Ministries, Departments and Agencies by Approved Authority 